\title{
The Challenges and Imperative of Tax System Reform in Nigeria
}

\author{
Nwosu M. Eze ${ }^{1}$, Tondo E. Iorwuese ${ }^{2} \&$ Wali B. Abba ${ }^{1}$ \\ ${ }^{1}$ Internal Audit, National Institute for Legislative Studies, National Assembly, Abuja, Nigeria \\ ${ }^{2}$ Accounts, National Institute for Legislative Studies, National Assembly, Abuja, Nigeria \\ Correspondence: Nwosu M. Eze, Internal Audit, National Institute for Legislative Studies, National Assembly, \\ Abuja, 14 Danube Street, Off IBB Way, Maitama- Abuja, Nigeria. Tel: 234-803-328-0224. E-mail: \\ mail4eze@yahoo.co.uk
}

Received: December 16, 2015

Accepted: January 13, 2016

Online Published: February 25, 2016

doi:10.5539/ijef.v8n3p151

URL: http://dx.doi.org/10.5539/ijef.v8n3p151

\begin{abstract}
Tax ranks next to the petroleum sector in terms of volume of public revenue generation in Nigeria as it is a major player in every society of the world. Government imposes taxes on the citizens in order to finance its activities and creates a conducive business environment for its citizens. In the process, responsibilities are assigned to three key elements namely, tax payers, tax authorities and the government. While tax authorities ensure effective collection of tax revenue to the government, tax payers are merely fulfilling their civic responsibilities and obligations. However, the tax system in Nigeria is confronted by myriad problems; multiplicity of taxation, especially among the three tiers of the government, low quality personnel, among others. This raises the need for reforms in the management of the tax system in Nigeria.
\end{abstract}

Keywords: tax system, taxpayers, tax authorities, tax reform, government, economic development

\section{Introduction}

Taxation is a major player in every economy of the world. It is never static but dynamic. The tax system is an opportunity for government to collect additional revenue needed in discharging its pressing obligations. A tax system offers itself as one of the most effective means of mobilizing a nation's internal resources and it lends itself to creating an environment conducive to the promotion of economic growth.

Taxes represent an instrument of fiscal policy used by government to manage the economic development of the nation. It constitutes a major aspect of the macro economy (Aneke, 2007). Payment of taxes is considered a primary civic duty of a bonafide citizen. As the saying goes, among the Americans, "The only sure things in life are death and taxes." The state's share of the income and earnings of the people and organisations thereof is in the form of taxes.

Traditionally, taxation is a main source of revenue to governments all over the world. Tax, thus, becomes a burden that everyone must bear to support the government. On their parts, governments utilise tax proceeds to render their traditional functions such as the provision of collective or public goods, that is, goods that cannot be divided among the separate members of the society but which must be used for the benefit of all. Such goods include the maintenance of law and order, defense against external aggression, regulation of trade and business to ensure social and economic justice. "The scope of government functions depends on the political and economic orientation of the members of the society, their needs, aspirations, willingness and ability to pay tax" (Olaofe, 2007, p. 1).

Taxation is a veritable and sustainable source of revenue for government and a tool for fiscal policy and macro-economic management. This fact was reinforced by Okezie (2003) who states that tax is a burden which every citizen must bear in order to sustain his or her government thus enabling that government perform certain basic functions to the benefit of those it governs. It follows that for any public payment to qualify as tax, it must have element of compulsory imposition, it must have an imposing authority and there must be an enabling law.

In the same vain Anyanwu (1997) defined taxation as the compulsory transfer or payment (or occasionally of goods and services) from private individuals, institutions or groups to the government. The main purpose of tax is to raise revenue to meet government expenditure and to redistribute wealth and management of the economy (Bhartia, 2009; in Ogbonna \& Appah, 2012). 
Tax is a compulsory levy imposed on a subject or upon his property by the government to provide security, social amenities and create conditions for the economic well-being of the society (Appah, 2004; Appah \& Oyandonghan, 2011). Nzotta (2007) cited in Ogbonna and Appah (2012) noted that taxes generally have allocational, distributional and stabilization functions. The allocation function of taxes entails the determination of the pattern of production, the goods that should be produced, who produces them, the relationship between the private and public sectors and the point of social balance between the two sectors. The distribution function of taxes relates to the manner in which the effective demand over economic goods is divided, among individuals in the society.

\subsection{Theories of Taxation}

According to Bhartia (2009) in Ogbonna and Appah (2012) a taxation theory may be derived on the assumption that there need not be any relationship between tax paid and benefits received from state activities. In this group, there are four theories, namely,

a. Socio-political theory

b. The expediency theory

c. Benefit received theory

d. Faculty theory

Socio political theory: This theory of taxation states that social and political objectives should be the major factors in selecting taxes. The theory advocated that a tax system should not be designed to serve individuals, but should be used to cure the ills of society as a whole. (Bhartia, 2009; in Ogbonna \& Appah, 2012).

Expediency theory: This theory asserts that every tax proposal must pass the test of practicality. It must be the only consideration weighing with the authorities in choosing a tax proposal. Economic and social objectives of the state as also the effects of a tax system should be treated irrelevant (Bhartia, 2009, in Ogbonna \& Appah, 2012).

Benefit received theory: This theory proceeds on the assumption that there is basically an exchange relationship between tax-payers and the state. The state provides certain goods and services to the members of the society and they contribute to the cost of these supplies in proportion to the benefits received (Bhartia, 2009; in Ogbonna \& Appah, 2012).

Faculty theory: That a citizen is to pay taxes just because he can, and his relative share in the total and Appah (2012).

Since taxation is dynamic, so reform (that is reviews) are necessary to effect the required changes in the national economy (Ola, 2001). Tax reform is an ongoing process with tax policy makers and tax administrators continually adopting the tax systems to reflect changing economic, social and political circumstances in the economy.

\section{Statement of the Problem}

Nigeria as a country is yet to develop a tax culture despite the fact that taxation has always been with us as a people. It is obvious that most wealthy people generally do not pay tax or tax due. Our basic problem, perhaps, is that the enforcement machinery of our tax laws is so innocuous that anybody can go against it without qualms. Those charged with its administration are more often than not so ill-equipped, so ill-trained and so neglected that they become disillusioned, frustrated and therefore hardly give their best services. Tax administration in Nigeria is generally poor. So many reasons have been adduced for the poor state of tax administration. Various tiers of government, tax administrators, tax practitioners and institutions have tried to improve tax administration machinery in the country. In spite of these efforts, there are still a myriad of problems militating against effective tax system in Nigeria.

\section{Objectives of the Study}

Anyanwu (1993) pointed out that there are three basic objectives of taxation. These are to raise revenue for the government, to regulate the economy and economic development and to control income and employment. According to Dwivedi (2004), Economic development is a sustained increase in per capita national output or net national product over a long period of time. It implies that the rate on increase in total output must be greater than the rate of population growth. Another quantification of economic development is that national output should be composed of such goods and services which satisfy the maximum want of the maximum number of people.

The Nigerian tax system according to the Presidential Committee on National tax policy (2008) described it 
expectations which include:

1). Encourage economic growth and development.

2). Generate stable revenue or resources needed by government to accomplish loadable projects and or investment for the benefit of the people.

3). Provide economic stabilization.

4). To pursue fairness and distributive equity.

5). Correction of market failure and imperfection.

Nightingale (2002) and Lyme and Oats (2010) in Abiola and Asiweh (2012) pointed out the following objectives:

1). Raising revenue to finance government expenditure.

2). Redistribution of wealth and income to promote the welfare and equality of the citizens.

3). Regulation of the economy thereby creating enabling environment for business to thrive.

Therefore, it might appear that taxes should play a central role in determining long-term growth Engen and Skinner (1996) In order for the above objectives to be achieved the tax administration policy need to be in compliance with the principle of taxation.

Akintoye and Tashie (2013) pointed out the importance of taxation in the activities of any government cannot be overemphasized. The world over, taxes is one major source of government revenue, however, not every national government have been able to effectively exploit this great opportunity of revenue generation. This can be attributed to a number reasons including the system of taxation; tax legislation; tax administration and policy issues; over reliance on other sources of revenue (such as foreign aid and grants); corrupt practices in the system - especially as it relates to the system of tax collection and behaviour of citizens towards tax payment; and ease of tax payment.

Okoyeuzu (2013) stated that the most important role of a tax system is its revenue-raising function. Governments therefore, impose taxes to finance the expenditures they undertake. Tax systems also have an important income distribution function. This recognizes a general perception that the tax system imposes a fair tax burden across taxpayers, which is essential to the effective operation of a voluntary compliance system of taxation. The Nigerian tax law is the embodiment of rules and regulations relating to tax revenue and various kinds of taxes. Such laws are continuously reviewed Okoyeuzu, (2013).

The Federal Inland Revenue Service (FIRS), for instance, which was first established as an operational arm of the Federal Board of Inland Revenue (FBIR) in 1993 but autonomous in 2007, was saddled with the responsibility of controlling and administering different taxes as well as accounting for all taxes collected. Another innovation by the government is the Tax Identification Number (TIN) programme, which has objective of carrying out a successful roll-out and implementation of TIN for Nigeria. Akintoye and Tashie (2013) the system developed a relational data base linked to all relevant stake holders in Nigerian tax administration. There is also the Joint Tax Board (JTB), amongst others, which are set up to address problems of the tax policies and its implementation, tax collection, and the tax payers' compliance in the country Akintoye and Tashie (2013).

The main objective of the paper is to find out the challenges facing the taxpayers and tax authorities in tax planning and administration in Nigeria. The specific objectives of the study include:

* To identify the stakeholders in Nigeria's tax system.

* To highlight the recent tax reforms in Nigeria's tax system and the roles of the various stakeholders.

* To establish the benefits of the tax reforms and compare them with those of other countries.

\section{Review of Literature}

\subsection{Meaning of Tax}

A tax is a levy by a government or its, agencies on individuals, companies and (or) on goods and services, homemade, imported, exported and so on. (Aguolu, 2007). Tax is a compulsory exaction of money or its equivalent by public authority for public purposes enforceable by law and it is not a payment for services rendered. According to lbraheem $(2003$, p. 5) "Tax is any compulsory contribution that is levied in cash or kind on a natural or artificial entity on the basis of a legislature by a public authority." Such an authority may be federal, regional or local by definition as long as it is not a private entity or organisation. For any other levy or charge to be termed a tax, it should not be for the usage of a government facility unless the usage of the facility is equally compulsory. "Tax can be levied' on income, profit, property or gifts" (lbraheem, 2003, p. 8). For any public payment to qualify as tax, it 
must have an element of compulsory imposition, it must have an imposing authority (federal, state or local governments); there must be an enabling law and the payment should not be for services enjoyed from government like payments for water rates, electricity consumption and so on. There are some cases, however, where government compels the citizens to pay for government services enjoyed and such payment can be described as tax, for example road taxes.

\subsection{Tax Authorities in Nigeria}

The relevant tax authorities in the three tiers of government are as follows Okauru (2011).

1). The Federal Board of Inland Revenue has power to legislate on taxation of incomes, transactions, capital gains and stamp duty and power to collect taxes on incomes, transactions capital gains and stamp duty of companies and individuals within its jurisdiction and as provided in the Constitution and enabling laws in that respect.

2). The State Board of Internal Revenue: Power to collect taxes on incomes or profits, capital gains and stamp duty from individuals resident within the State as provided in the Constitution and other laws in that respect. Power to legislate on the collection of taxes, fees, levies and charges by Local Government.

3). The Local Government Revenue Committee Power to collect taxes, fees, charges and levies as provided under the Constitution and other enabling laws in that respect.

\subsection{The Federal Board of Inland Revenue}

The board is solely responsible for the assessment and collection of taxes from corporate and non-resident individuals and from members of the armed forces as provided for by the Companies income Tax Act (1961). Federal taxes include Company income Tax; Withholding Tax on companies; Personal Income Tax on residents of the Federal Capital Territory (FCT), and non-resident individuals; Petroleum Profit Tax. Education Tax, Capital Gains Tax on residents of FCT, and corporate body and non-resident individuals, stamp duties on corporate bodies and residents of the FCT. It also collects personal income tax in respect of:

i. Members of the Armed Forces of the Federation.

ii. Members of the Nigeria Police 'Force.

iii. Residents of the FCT, Abuja.

iv. Staff of the Ministry of Foreign Affairs and non-resident persons (Companies Income Tax Act, 1961).

\subsection{State Board of Internal Revenue}

At the state level, we have the Board of internal Revenue whose operational arm is the state internal revenue service, which is solely in charge of applying the personal income tax law and road traffic regulations. The state internal revenue service is headed by a Chairman/CEO and is responsible for the collection and accounting for:

i. Personal Income Tax;

a) Pay-As-You-Earn (PAYE);

b) Direct Taxation (Self-Assessment);

c) Withholding Tax (Individuals only).

ii. Capital Gains Tax (Individuals only);

iii. Stamp duties on instruments executed by individuals;

iv. Pools betting and lotteries, Gaming and Casino taxes;

v. Road taxes;

vi. Business Premises Registration fee;

vii. Development Levy (Individuals only);

viii. Naming of street registration fee in the state capital;

ix. Right of occupancy fees on land owned by the state government in urban areas of the state;

x. Market taxes and levies where state finance is involved. (Weris, 2000).

\subsection{Local Government Revenue Committee}

The committee is charged with the responsibility for the assessment and collection of all taxes, fines, fees and rates under its jurisdiction and shall account for all amounts so collected in a manner to be prescribed by the chairman of 
the local government. PITA 1993 (S. 85D), which established the committee, directs that it shall be autonomous of the local government treasury and shall be responsible for the day-to-day administration of the Local Government Revenue Department, which is its operational arm. The committee is headed by a Chairman/CEO and is responsible for:

1) Shops and kiosks' rates;

2) Tenement rates;

3) On and Off Liquor license fees;

4) Slaughter slab fees;

5) Marriage, birth and death registration fees;

6) Naming of streets registration fee, excluding any street in the state capital.

7) Right of occupancy fees on lands in rural areas excluding those collectible by the federal and state governments.

8) Market taxes and levies excluding any market where state finance is involved.

9) Motor park levies.

10) Domestic animal license fees.

11) Bicycle, truck, canoe, wheel barrow and cart fees.

12) Cattle tax-payable by cattle.

13) Merriment and road closure levy.

14) Radio and television license fees (other than radio and television transmitter).

15) Vehicle radio license fees (to be imposed by the local government of the state in which the car is registered).

16) Wrong parking charges.

17) Public convenience, sewage and refuse disposal fees.

18) Customary burial ground permit fees.

19) Religious places establishment permit fees.

20) Signboard and advertisement.

\subsection{Tax Administration in Nigeria}

An efficient and effective system of tax administration, there must always be a consideration of the challenges which militate against the creation and maintenance of such a system. Okauru (2011) In Nigeria most of the issues faced cut across the three tiers of Government. These issues are without reference to which tier are affected or otherwise. The major challenges faced in tax administration in Nigeria include:

a. Lack of an overall understanding of the role of taxation in national development.

b. Dependence on oil revenues leading to a neglect of taxation as a source of revenue.

c. Lack of sufficient political support for the tax administration.

d. Level of business activity in the economy.

e. Issues within the tax administration set up, which include.

Capacity issues quality and quantity of human resource;

Technology issues, manual system of tax operations, lack of records, absence of automated systems;

Low level of taxpayer education and enlightenment;

Funding challenges.

a. Large informal sector outside the tax net.

b. Poor attitude to taxation, lack of tax culture, low awareness amongst taxpayers.

c. Low level of voluntary compliance.

d. Deliberate evasion and non-compliance.

e. Multiple taxation. 
f. Corruption, leakage and diversion of tax revenues, by tax officials before and during collection, by Government officials after distribution.

g. Lack of accountability for tax revenue.

h. Lack of inter-governmental collaboration, co-operation and co-ordination between different tiers and agencies of Government.

i. Lack of sufficient Government impact on citizens.

The above issues are not exhaustive, most of the challenges faced by tax authorities can be situated within the above list. Okauru (2011).

Okauru (2011) also suggested the following workable and effective solutions to the challenges facing tax administration and collection. These include:

Need to Institutionalize Tax Culture at all levels of Government and amongst Citizens: There is generally an absence of a strong tax culture amongst Nigerians. This cuts across all tiers of Government and affects all the citizens irrespective of our backgrounds, experience and station in life. Okauru (2011) this will enable the nation to obtain the maximum value from our tax system, in terms of collection of revenue and availability of resources for developmental projects.

Improvement of Investment and Business Climate by Government: Revenue generating agencies are usually major beneficiaries of investment and business climate as this greatly enhances their ability to discharge their primary responsibility of revenue generation. Okauru (2011) The FIRS in particular has been able to record significant improvement in tax collection during periods when the economy has thrived. It is therefore necessary for all tiers of Government to see it as a primary responsibility of Government to create a conducive atmosphere for economic activities from which revenue is realized in the form of taxes, charges, fees etc.

Provision of Support to Tax Authorities: Without support from the highest levels of Government, tax authorities would be unable to effectively operate and discharge their duties as they will be spend time, which could be otherwise utilized to manage these recurring issues. It is therefore necessary for Government, especially the Executive and Legislature to provide hands on support to tax authorities in all areas. At the Federal level the FIRS has received significant support in several areas, which greatly assisted in achieving the milestones, which the FIRS has been able to achieve.

Furthermore, tax administration consists of the tax authorities and the organs of "tax 'administration. The Nigerian Tax Law (Act 121 of 1998) defines tax authority to mean the Federal Board of inland-Revenue (FBIR) the State Board of internal Revenue, or the Local Government Revenue Committee. Practice guidelines and newspaper are published by the Federal Inland Revenue Service (FIRS) - the operational arm of FBIR and the joint tax board from time-time to address interpretation issues and making of clarification where necessary.

Olaofe (2007) and Ibraheem (2007) concur that the hindrances to effective system of tax administration in Nigeria include:

* Poor attitude of taxpayers.

* Shortage of tax personnel in terms of quality and quantity.

* Poor provision of logistics including vehicles, radio equipment, telephone, funds, etc;

* Poor community development and pattern of government expenditure leading to high tax evasion as people do not see the reason for paying tax;

* Activities of collecting agents including late remittances of collection, misappropriation of collections or inadequate tax deductions;

* Lack of cooperation from other government agencies and departments as it is difficult to have a complete audit trail of taxable events;

* Absence of information for taxpayers as they are not sufficiently educated and enlightened on the provisions of various tax laws; and

* Lack of enforcement power as tax administrators do not have powers to arrest and detain tax defaulters.

\subsection{Code of Ethics for Efficient Tax Administration}

The Joint Tax Board (1999) approves the following code of ethics for efficient tax administration in Nigeria. Tax officials are mandated to religiously observe the provisions of the code of ethics. The tax officials shall: 
* Pay his tax promptly, correctly and happily as examples to the tax-paying public;

* Be honest and impartial in his dealing with the taxpayers;

* Be courteous, professional and painstaking towards the taxpayers;

* Seek to encourage the taxpayers to pay his taxes promptly, eagerly and correctly;

* Not collude with the taxpayers to engage in any form of tax planning, tax evasion or to unduly reduce, withhold, delay or refuse the payment of tax;

* Seek to implement the tax law fairly, faithfully and equitably, irrespective of the status of the persons and organisations concerned or goods and services that are involved;

* Refuse any form of gratification, favour or assistance from taxpayers generally such that the taxpayers obligation is thereby not determined;

* Display competence and professionalism in the discharge of his duties;

* Not engage in any activity that may bring the image and reputation of the tax administration to ridicule or contempt;

* Not assault or manhandle the taxpayer nor use foul and unethical language in communicating with the taxpayers but shall follow due process of law in the discharge of his duties;

* Seek to ensure that taxes are correctly collected and remitted to the public services and demonstrate diligence, capability and genuine interest in the discharge of his duties; and

* Seek to be knowledgeable in the tax laws and practice and be current in tax affairs by keeping abreast of fiscal developments in Nigeria and elsewhere.

\subsection{Tax Reforms and Tax Planning in Nigeria}

The Longman's Dictionary of Contemporary English (2004) describes a reform as "to change a system, law, organisation etc. so that it operates in a fairer or more effective way." The dictionary reiterates that a reform improves a system and removes unfairness. Alli (2007) lists the following reasons for tax reforms:

i. To bridge the gap between the national development needs and the funding of the needs;

ii. The need to ensure taxation as a fiscal policy instrument to achieving improved service delivery to the public.

iii. To improve on the level of tax derivable from non-oil activities, vis-a-vis revenue from oil activities;

iv. To constantly review the tax laws to reduce/manage tax evasion and avoidance;

v. To improve the tax administration to make it more responsive, reliable, skillful and taxpayer friendly;

vi. To achieve other fiscal objectives.

A background on the tax reform efforts of the federal government from 2001 to date shows that the recent tax reforms can be categorised into two major groups, according to the year they were introduced; thus the 2001 and 2004 tax reforms.

\subsubsection{The 2001 Tax Reforms Proposal}

In January 2001, Mallam Adamu Ciroma, the then minister of finance, introduced the proposed amendments to four Nigerian tax laws, namely: The Companies Income Tax Act, the Personal Income Tax Act, the Petroleum Profit Tax Act, and the Value Added Tax Act. The highlights of the amendments that the federal government of Nigeria (2001) proposes include:

\subsubsection{On the Companies Income Tax Act (CITA)}

* Raising the ceiling of the foreign loan that qualify for tax relief from N150,000 to N5,000,000.

* Amending the conditions for granting tax exemption to profit earned from export of manufactured goods - 50 per cent of the manufactured goods must be for export and not less than 75 per cent of the export proceed is to be repatriated to Nigeria through approved channels.

* Substitution of the term "Investment Allowance" for "Investment Tax Credit".

* Removing the contradictions in the self-assessment filing system as contained in SAGA, 40B, 47, 50, 51, 54 and 59 of CITA. 


\subsubsection{On the Personal Income Tax Act (PITA)}

* Amendment seeking exemption from tax for pensions payable to public servants.

* Amendment for upward review of transport allowance from N15,000 to N20,000 and housing allowance from N100,000 to N150,000.

* Amendment seeking for the expansion of the bands of the taxable incomes to which the various income tax rates apply.

4.8.4 On the Petroleum Profit Tax Act (PPTA)

* Amendment seeking for provision of interests on inter-company loans within the oil industry as allowable deductions.

* Amendment seeking to review some of the incentives earlier granted to companies in the oil industry to be in line with current realities, example, the need to base the calculation of investment tax credit on qualifying capital expenditure rather than on chargeable profits.

4.8.5 On the Value Added Tax Act (VAT)

* To include the "value of services" in the definition of assessable value. Before now it is the "value of goods" that the law recognised.

* Amendment in favour of multiple registrations of VAT, against central registration as presently recognized by the law.

* An amendment to section 8A and 10A to substitute the term "taxable person" for the word "contractor."

* Authorisation of the Accountant-General of the federation to deduct unremitted VAT by government agencies from allocations due to the bodies.

* Amendment to enable the aggrieved taxpayers to appeal to the VAT tribunal and to empower government to prosecute VAT defaulters before the VAT tribunal.

* Restriction of exemption of food items to those produced locally as an anti-avoidance strategy.

\section{General}

* Policy directed to the improvement of tax administration.

* Widening of tax base and encouragement of voluntary tax compliance.

\subsubsection{The 2004 Tax Reforms Proposal}

The latest tax reforms process was embarked upon by the government by instituting a study group on the Nigerian tax system made up of individuals from business, academia and government with an injunction to study the tax laws and recommend the appropriate reforms in general and their impact on the overall economy. As a fallout from the study group, nine bills on tax reforms were approved by the Federal Executive Council for consideration at the National Assembly. They are:

* A bill for an Act to establish the Federal Inland Revenue Service as an autonomous service

* A bill for an Act to amend CITA,

* A bill for an Act to amend PPTA,

* A bill for an Act to amend PITA,

* A bill for an Act to amend Value Added Tax Act,

* A bill for an Act to amend Education Tax Act,

* A bill for an Act to amend the Customs, Excise, Tariffs, etc. (Consolidation) Act,

* A bill for an Act to amend the National Sugar Development Council Act,

* A bill for an Act to amend the National Automotive Council Act.

The highlights of the bills as they affect the various Acts as released by the Federal Board of Inland Revenue (2004) are as follows:

4.8.7 On the Federal Inland Revenue Service as an Autonomous Service

* Repeal part one of CITA, dissolve FBIR and establish an autonomous parastatal called 'Federal Inland Revenue Service (FIRS)". 
* Improve funding for enhanced effectiveness i.e., amount not less than $4 \%$ of all non-oil revenue collected by the service in the preceding year as may be appropriate by the National Assembly as administrative charge and cost of collection);

* Institute a clear tax refund procedure;

* Establish the FIRS management board to be known as the Federal Inland Revenue Service Board (FIRSB);

* Empower the FIRSB to have overall control of the FIRS;

* The President to approve from time-to-time, the emoluments and "allowances of the chairman and members of the board;

* The service to have an executive chairman to be appointed by the President and who shall on the recommendation of the minister appoint four full-time deputy chairmen from among the directors of the service;

* The service shall have the following functions:

— To administer the various federal tax laws in Nigeria;

- To carry out all of the functions that were initially performed by the FBIR; and

- To perform any other related tax functions as provided by the law.

4.8.8 On the Bill for an Act to Amend Companies Income Tax Act

* To make the Act more responsive to the tax reform policies of the federal government;

* To make donations to tertiary and research institutions tax deductible;

* To make officers of companies responsible and accountable for Acts or omissions of their companies;

* To enhance the implementation and effectiveness of the Act; and

* To amend penalty provisions.

4.8.9 On the Bill to Amend the Petroleum Profits Tax Act

* To make the Act more responsive to the tax reform policies of the federal government;

* To make NNPC to provide FIRS with comprehensive information on joint venture contracts, production sharing contracts, etc, for effective taxation of the petroleum sector:

* To make donations to tertiary and research institutions tax deductible,

* To enhance the implementation and effectiveness of the Act; and

* To amend penalty provisions.

4.9 On the Bill to Amend the Personal Income Tax Act

* To make the Act more responsive to the tax reform policies of the federal government;

* To introduce a more equitable income tax structure in order to encourage voluntary compliance;

* To create consolidated emoluments and allowances for employees as percentage of total emoluments, (i.e., personal relief to be $40 \%$ of the gross emolument while the balance of $60 \%$ is to be taxable in accordance with the income tax table, as proposed for legislative amendments);

* To enhance the implementation and effectiveness of the tax system; and;

* To amend penalty provisions.

4.9.1 On the Bill for an Act to Amend the Value Added Tax Act

* To make the Act more responsive to the tax reform policies of the federal government to remove all inherent ambiguities in the law;

* To introduce zero-rated goods and services;

* To increase VAT rate from $5 \%$ to $10 \%$ (i.e. to compensate for reduction in revenue from the personal income tax);

* To enhance implementation and effectiveness;

* To change revenue allocation to align with Federation Accounts formula. 
4.9.2 On the Bill for an Act to Amend the Education Tax Act

* To rename the Education Tax Fund as Education Trust Fund;

* To provide alternative source of funding for the Education Fund by abolishing Education tax of $2 \%$ of a company's assessable profit; and

* To fund the new Education Trust Fund by dedication of a percentage of the Consolidated Revenue Fund (though subject to appropriation and donations).

4.9.3 On the Bill for an Act to Amend the Customs, Excise Tariffs, etc (Consolidation) Act

* To abolish the 5\% levy on Cost, Insurance and Freight (CIF) value of imported sugar to avoid multiple taxation.

4.9.4 On the Bill for an Act to Amend the National Sugar Development Council Act

* To abolish the $10 \%$ surcharge on sugar imports to avoid multiple taxation; and

* To make provisions for alternate funding of the existing national development council through budgetary allocation.

4.9.5 On the Bill for an Act to Amend the National Automotive Council Act

* To abolish the $2 \%$ of the Cost, Insurance and Freight (CIF) value of all imported Fully Built Unit (FBU) auto component spare parts, Completely Knocked Down (CKD) and raw materials brought in for the automotive sub-sector in order to avoid multiple taxation; and

* To make provisions for the alternate funding of the existing National Automotive Council.

\section{The Tax Planning Scheme}

Tax planning refers to the drawn-up tax strategy, goal, forecast, estimate, budget or a plan with the aim to raise revenue and manage the economy or to reduce the burden of tax as the case may be. Tomety (2007, p. 21) asserts that "the goal of tax planning is to arrange our financial affairs so as to minimise taxes without breaching the tax law of the land where the income are earned".

\subsection{The Government Fiscal Planning}

The government applies certain fiscal planning tools to achieve effective tax planning. The tools include annual budgets, short-term and long-term economic development plans and specific economic interventions. Example is the NDDC. Through these tools governments implement or apply the following tax planning techniques (Alli: 2007):

a) Tariffs

* Taxes, * Levies, * Custom Duties. * Excise Duties.

\section{b) Incentives}

* Free Trade Zones (such as oil and gas free zone, Lekki Free Zone, Calabar Free Zone, etc),

* Pioneer Products and Tax Holiday,

* Specific Exemptions and Special Tax Regimes,

* Other concessions such as Export Rebate/Export Expansion Grants, Accelerated Capital Allowances, Investment Tax Credits, Rural Investment Allowance, etc).

\subsection{Private Sector (Taxpayer) Planning}

An effective taxpayer planning must provide adequate tax plan for compliance areas and which must be directed towards the object of meeting corporate tax obligations with a minimum of friction with the tax authorities at each tier of government. These areas include (Aneke 2007).

* Failure to file requirement returns,

* Failure to meet advance payment requirements

* Failure to pay on or in time at deadlines,

* Failure to properly execute tax and related forms for processing through the tax system.

\section{The underlisted tools are necessary for effective tax planning:}

i. Use of a master tax calendar; The calendar must carry due dates for every type of requirement that must 
have to be met during the year

ii. Use of computers to provide workload schedules,

iii. Use of organisers,

iv. Use of trackers such as for payments and receipts as well as expatriates tax calculations. Tomety (2007) identifies the cost associated with bad compliance plan or lack of planning to include:

* Failure to file penalty,

* Failure to pay penalty,

* I nterest on delinquent amounts.

* Loss of concession to pay,

* Loss of $1 \%$ bonus concession,

* Annual sanction,

* Tax investigation,

* Civil action,

* Criminal action.

Alli (2007), Aneke (2007) and lshola (2005) agree that strategic tax planning for maximum benefit to the taxpayer can be achieved in the following ways:

\subsection{Planning through the Choice of Form of Business Organization}

* Choice of form of business organisation such as sole proprietorship, partnership, limited liability company, trust, etc.

* Tax rate for company income tax is $30 \%$ on total profit while the upper marginal rate is at $25 \%$ for individuals and partners are 5\% while that of companies are mostly at $10 \%$.

* Individuals and partners enjoy deductions on capital allowances on business income, in addition to personal and other relief allowances which are not extended to companies etc. Tax Holidays and incentives are generally extended to companies.

\subsection{Planning through the Choice of Appropriate Commencement Date for Tax Effectiveness}

* The choice of a tax beneficial accounting date can impact the amount of tax liability of a company.

* The tax law requires that the accounts prepared by the taxpayer form the basis for determining how much tax is payable and when the tax is payable.

* Choice of assessment year.

5.5 Planning the Cessation Date for Tax Effectiveness

* Roll back of unclaimed loss relief.

* Roll back of unclaimed capital allowances.

\subsection{International Tax Planning for Effectiveness}

This includes the choice of appropriate vehicle for foreign investments, examples: equity, debt, equity and debt, thin capitalization, treaty shopping and the use of special purpose vehicles (SPVs).

The choice of an appropriate tax planning scheme will reduce the tax burden of the taxpayer (Tomety, 2007; and Olaofe, 2007).

\section{Tax Reforms in Other Countries}

Recent tax reforms from other international tax jurisdictions have been identified as models for developing countries. The reforms in the developed countries such as the United Kingdom, the United States, Canada and Australia are hereby highlighted.

i. Transfer pricing is extended to related enterprises,

ii. Scheduler reforms on treatment of capital assets, differences in the tax treatment of trading and investment income,

iii. Leases - capital allowance being claimable by the lessee, under finance lease arrangements, instead of the lessor, which was the original practice, 
iv. Exemptions are introduced for multiple of food products described as basic groceries or essential foods with some exemptions example, hot meat pie is generally taxable unless they are specially heated at the customer's request and have been reheated from cold as opposed to being cooked.

In the United States, the recent reform is on domestic manufacturing with particular reference to research and development cost incentives to the industries and also to the service industries. In Canada, most food items have been put under zero rates, with the exception of some discretionary items such as snack food, confectionery, beverages, restaurant meals and take away foods.

Australia is not left alone as it has introduced the under listed reforms

a) Major restructure of the community revenue base through the introduction of wine equalisation tax and luxury car tax,

b) Reproduction in tax rate and increased family benefits,

c) Overhaul of how people pay their taxes during the year through introducing Pay-As-You-Go system for installments and withholding taxes,

d) Establishment of the new Australian Business Register, and registration of millions of businesses,

e) Registration and endorsement of exemption and gift deductibility status of charities,

f) An extension of the diesel fuel rebate for off-road vehicles and the introduction of the new diesel and alternative grant scheme for certain on-road transport,

g) Fuel sales grant scheme for regional and remote service stations,

h) New product stewardship arrangement for waste oil, by collecting levy on relevant oil and paying benefits to companies recycling waste oil.

i) Transfer of Australian Custom Service to be administered by the Australian Tax Office

It can be observed that all of the above reforms fall under the various spheres of reforms as they affect the tax authorities, governments, administrators and of course, the taxpayers.

\section{Challenges of Tax Authorities and Taxpayers}

Perhaps, the greatest drawback to the tax reforms in Nigeria is the long time lag between the submission of proposed amendment bills by the Federal Executive and the time used for debating and passing of the bills into laws by the National Assembly. It is regrettable that most of the proposed amendments to the National Assembly since January 2001 are yet to be passed by the Assembly. The same applies to the amendments proposed in the 2004 bill (Alli, 2007). Obviously, by the time the bills are finally passed by the Assembly (if they ever be) some of the provisions of the bills may have become stale, outdated and irrelevant (Alli, 2007).

Interestingly, most tax reforms today are characterised by rare reduction but more work is required to broaden the tax base in order to increase tax revenue accruable to the government. Tomety, 2007) observed that companies' income tax has reduced from 50\%, 54\%, 40\% and 30\% between 1991 and 1996.

Government has planned to pay lower basic salary and monetised allowance with increased benefit in kind. The advantage here to the taxpayer is that tax is paid on the lower monetised income together with the taxable element of the benefit in kind (Aneke, 2007) one might need to mention here that the lower the basic salary, housing and transport, then the lower the leave allowance and pension contribution of the respective employees.

This will generally increase the net income left in the hands of the taxpayer. Ariwodola (2000) is of the opinion that the Nigerian tax system has been made nonsense of at the local government level as most councils are either shamefully ignorant of the legal framework for their tax administration machineries or are flagrantly abusing same for personal gains. Despite a federal law issued in 1998 detailing the types of taxes, fees and rates chargeable by states and local governments, most of the councils disregard these restrictive provisions. Olaofe (2007) observes that some councils illegally collect road taxes, ground rent, business premises fees and so many other form of local taxes, fees and rates not recognised by the federal law. In Nigeria, most local councils have down played the absolute need for them to enact bye-laws to enable them collect approved taxes and rates, but rather quote the federal Constitution as their authority.

The combined efforts of the stakeholders in Nigeria's tax system towards addressing the above issues will surely improve the country's tax system.

\section{Conclusion}

The need for a reformed tax system cannot be over emphasised. A tax reform process and a tax planning process 
need to be embraced by all and seen as among the ways to achieve economic development and growth in Nigeria. It also enables our tax system to be internationally relevant, as practicable as possible as well as increasing foreign investment inflows.

-Bringing the informal sector into the tax net. Given the large amount of persons outside the tax system, it is necessary to bring in the large number of person into the tax net to enable them contribute their quota to the tax system and this can only be achieved with hands on support from Government;

-Enforcement of tax laws to minimize the incidence of evasion, willful default, diversion of tax revenue and corrupt practices by taxpayers and tax officials.

Addressing Multiple Taxation within the Tax System: In tackling multiple, significant effort has been made by the Presidency, the National Economic Council (NEC) Ministry of Finance, the FIRS and the Joint Tax Board to address the issue in a holistic manner. The National Tax Policy has also recognized multiple taxation as one of the negative practices in the tax system, which all stakeholders must collaborate to address.

Improved Accountability and Communication of uses to which Tax Revenue is put: This is another powerful tool, which can be utilized to improve the ability of tax authorities to achieve efficiency in collection of revenue. Where Government is accountable for revenue collected and taxpayers have free and easy access to tax information, it aids voluntary compliance, as taxpayers will see that they have a stake in the tax system as the revenue collected is utilized on their behalf.

Another important tool in improving efficiency within the tax system is improved and increased inter-governmental and inter-agency collaboration, co-operation and co-ordination - this entails collaboration by authorities in the three tiers of Government on issues, which affect them collectively and individually. In this regard, the Joint Tax Board is pushing through the Unique Tax Identification Number (U-TIN) Project, which seeks to create an automated national database of all taxpayers in Nigeria at all levels of Government. This is being co-founded by all the States and the Federal Government, through the FIRS and the Joint Tax Board. It is a great example of what can be achieved through inter-governmental collaboration. The U-TIN system will allow for easier identification of taxpayers across the country and resolve issues such as; multiple taxation, conflicts over tax jurisdiction by different States or Local Governments and also allow Government to utilize the data for several other purposes. Also the National Tax Policy, which was supported by all tiers of Government and the implementation of which all tiers of Government are expected to ensure in their respective jurisdictions. There are several other areas, where collaboration and co-operation is required, such as exchange of information, prompt remittance of taxes collected on behalf of other agencies or tiers of Government and payment of tax arrears and debts owed by one tier to another. Okauru (2011).

The symbiotic relationship between taxation and public expenditure is evident in the fact that taxpayers or revenue paying public are well disposed to perform their civic duties willingly when they see evidence of public expenditure which they can identify with or benefit directly from. Many Nigerian will want to see, for example, efficient public transportation, efficient waste collection, regular water and electricity supply system, well-maintained and well-drained roads and sidewalks, availability of educational facilities and functional health services in the country. Improvements, if not perfections, can only be released and sustained with a sound tax system made possible by constant tax reforms, efficient tax administration and cooperative tax-paying public.

\section{Recommendations}

The underlisted recommendations are offered to achieve an effective tax system in Nigeria:

i. The government that spends tax revenue should have some degree of accountability so that citizens make the connection between tax and fees they pay and services they receive in return. (Olaofe, 2000; and Alli, 2007). Government is advised to account for and spend money collected as tax in order to build patriotism in Nigerians.

ii. A company has the responsibility to set the climate in terms of relationships between the company and the various tax authorities or its agencies. Management should seek the advice of professionals and consultants on tax planning techniques in order reduce the company's tax burden rather than attempting avoidance which is a criminal offence.

iii. In view of the fact that local councils are left with very few direct sources of internal revenue, it is suggested that local government councils should jointly address the federal government and the National Assembly on the unfortunate imbalance, rather than creating the menacing issue of multiplicity of taxes. This will make very difficult, if not impossible, for state and federal government to collect taxes and fees due to the local government councils. 


\section{References}

Abdulrazaq, M. I. (n. d.). Rent Tax Measures, Effectives, Problems and Improvements.

Abiola, J., \& Asiweh, M. (2012). Impact of Tax Administration on Government Revenue in a Developing Economy a Case Study of Nigeria. Int. J. Bus. and Soc. Sci., 3(8).

Adeesola, S. M. (n. d.). Income Tax Laws and Administration in Nigeria. Obafemi Awolowo, Nigeria: University Press.

Aguolu, O. (2004). Taxation and Tax Management in Nigeria. Enugu, Maridian Associates, p. 8.

Akintoye, I. R., \& Tashie, G. A. (2013). The Effect of Tax Compliance on Economic Growth and Developing in Nigeria, West Africa. British J. Arts and Soc. Sci., 2(2).

Anyanwu, J. C. (1997). Nigerian Public Finance. Onitsha: Joanne Educational Publishers.

Appah, E. (2010). The Problems of Tax Planning and Administration in Nigeria: The Federal and State Govts. Experience. Int. J. Lab. Organ. Psychol., 4(1-2), 1-14.

Ariwodola, J. A. (2000). Companies Taxation in Nigeria (pp. 132-136). Lagos J. A. A. Nigeria Ltd.

Arongundade, J. A. (2005). Nigeria Income Tax and Its International Dimension.

Bhartia, H. L. (2009). Public Finance (14th ed.). Vikas Publishing House PVT Ltd, New Delhi.

Dwivedi, D. N. (2004). Managerial Economics (6th ed.). New Delhi: Vikas Publishing House PVT Ltd.

Fara Vola, G. O. Guide to Nigerian Taxes.

Federal Republic of Nigeria. (1961). Companies income -Tax Act.

Federal Republic of Nigeria. (1979). Petroleum Profit Tax Act.

Federal Republic of Nigeria. (1993). Personal Income Tax Act.

Federal Republic of Nigeria. (1993). Value Added Tax Act.

FIRS. (2007). Retrieved from http://www.Tat.gov.ng/sites/default/files/docs/TAT_ESTABLISHMENT-ACT.pdf 1shola, K. A. (2005). Companies and Personal Taxation in Nigeria (pp. 143-170). Indemac Nig. Publishers Ltd.

Micah, L. C., \& Umobong, A. A. (2012). Tax system in Nigeria- Challenges and the WayForward. Res. J. Finance and Accounting, 3(5).

Nwosu, M. E. (2013). Principles of Accounting with Questions and Suggested Solutions. Abuja, Nigeria: Petra Digital Press.

Ogbonna, G. N., \& Appah, E. (2012). Impact of Tax Reforms and Economic Growth in Nigeria: A Time Series Analysis. Current Res. J. Soc. Sci., 4(1), 62-68.

Ogundele, E. A. (1999). Element of Taxation. Lagos: Libriserve Limited.

Okauru, I. O. (2011). Effective and Efficient Tax Collection and Administration in Nigerian in the Three Tiers of Government. Retrieved from http://www.rmafc.gov.ng/2011

Okezie, S. A. (2003). Tax Administration in Nigeria: Accountability Fairness (pp. 1-22). The Institute of Chartered Accountants of Nigeria MCPE, Lagos.

Ola, C. S. (2001). Income Tax Law and Practice in Nigeria (pp.11-72). Lbadan: Dalag Prints and Pak Ltd.

Oyebamiji, J. O. (2010). Principles and Practice of Taxation.

Presidential Committee on National Tax Policy. (2008). Draft Document on the National Tax Policy. Retrieved from http://www.scribd.com/doc/10063735/National-Tax-PolicyDraft-Updated

Weris, W. N. (2000). Elements of Personal Income Taxation (pp. 1-13). Buguma; Buvata International Ltd.

\section{Copyrights}

Copyright for this article is retained by the author(s), with first publication rights granted to the journal.

This is an open-access article distributed under the terms and conditions of the Creative Commons Attribution license (http://creativecommons.org/licenses/by/3.0/). 